\title{
Mapping the Responsibilities to Protect: A Typology of International Duties
}

\author{
James Pattison \\ University of Manchester \\ james.pattison@manchester.ac.uk
}

\begin{abstract}
The international responsibility to protect is the most important and value-added element of the responsibility to protect (R2P) doctrine. However, the existing accounts of the international responsibilities of R2P are often fairly ad hoc and not clearly systematised, largely focusing on particular responsibilities. Consequently, this article provides a typology of the various international responsibilities required by the R2P. In particular, it presents six types of international responsibility to protect: (1) the responsibility to undertake direct action; (2) the responsibility to support direct action; (3) the responsibility to authorise; (4) the responsibility not to act; (5) the responsibility to advance R2P; and (6) the responsibility to reform. In doing so, it will clarify how these responsibilities hang together and highlight underappreciated responsibilities.
\end{abstract}

\section{Keywords}

duty - international responsibility - obligation - R2P

\section{Introduction}

The notion of the international responsibility to protect is widely accepted to be the most important and value-added element of the responsibility to protect (R2P) doctrine. ${ }^{1}$ That is, when states are unable or unwilling to protect

1 This article was written whilst holding a research fellowship from the Arts and Humanities Research Council (AHRC) for the project, 'The Ethics of the Alternatives to War' (AH/Lo03783/1). The author would like to thank the AHRC for their support. The author would

(C) JAMES PATTISON, 2015 | DOI 10.1163/1875984X-00702006

This is an open-access article distributed under the terms of the Creative Commons Attribution-

NonCommercial 3.o. Unported (CC BY-NC 3.o) License, http:/fcreativecommons org/licenses/by-nc/3ro/ 01:28:26PM 
their populations from mass atrocities, the international community has a responsibility to assist them (under R2P's pillar two) or coerce them to do so (under R2P's pillar three). The 2001 report of the International Commission on Intervention and State Sovereignty (ICISS) on R2P provides perhaps the most detailed account of the various responsibilities involved, dividing it into the responsibilities to 'prevent', to 'react', and to 'rebuild.' ${ }^{2}$ But, of course, the account of the R2P adopted at the 2005 UN World Summit, and that has since developed, is different to the account of the $\mathrm{R} 2 \mathrm{P}$ in this report. Various responsibilities of the R2P in its post-2005 incarnation are often mooted, including the 'responsibility to prosecute', ${ }^{3}$ the 'duty of conduct' $/$ 'responsibility to try,', the 'responsibility not to veto, ${ }^{6}$ the duty to undertake military intervention, ${ }^{7}$ and, less often, the 'responsibility to rebuild'. ${ }^{8}$ However, the existing accounts of the international responsibilities of R2P in its post-2005 incarnation are often fairly $a d$ hoc and are not clearly systematised, largely focusing on particular responsibilities.

Accordingly, this article aims to provide a systematic account of the various international responsibilities required by the R2P. It attempts to offer a helpful

2 International Commission on Intervention and State Sovereignty (ICISS), The Responsibility to Protect: Report of the International Commission on Intervention and State Sovereignty (Ottawa: International Development Research Centre, 2001).

3 See Adrian Gallagher and Jason Ralph, 'Legitimacy Faultlines in International Society: The Responsibility to Protect and Prosecute after Libya', Review of International Studies, 41/3: 553-73 (2015), at 553 n. 2.

4 Jennifer M. Welsh, 'Norm Contestation and the Responsibility to Protect', Global Responsibility to Protect, 5/4: 365-96 (2013); Jennifer M. Welsh, 'Implementing the "Responsibility to Protect”: Catalysing Debate and Building Capacity', in Alexander Betts \& Phil Orchard (eds), Implementation and World Politics: How International Norms Change Practice (Oxford: Oxford University Press, 2014), pp. 124-43.

5 Alex J. Bellamy, The Responsibility to Protect: A Defense (Oxford: Oxford University Press, 2015); Alex J. Bellamy, 'The Responsibility to Protect Turns Ten', Ethics \& International Affairs, 29/2: 161-85 (2015), p. 171. Bellamy credits this notion to Edward Luck, the first UN Special Representative on R2P. Also see Luke Glanville, 'Does R2P Matter? Interpreting the Impact of a Norm', unpublished paper.

6 Citizens for Global Solutions, 'The Responsibility Not To Veto: A Way Forward', Updated Version, 2014, globalsolutions.org/files/public/documents/RN2V_White_Paper_CGS.pdf

7 Kok-Chor Tan, 'Humanitarian Intervention as a Duty', Global Responsibility to Protect [this issue].

8 Robert Pape, 'When Duty Calls: A Pragmatic Standard of Humanitarian Intervention', International Security, 37/1: 41-80 (2012), p. 51. I should add here that Pape's article is widely viewed as making several basic errors in understanding R2P. See, for instance, the replies by Gareth Evans and Ramesh Thakur, 'Correspondence: Humanitarian Intervention and the Responsibility to Protect', International Security, 37/4: 199-214 (2013). 
account of how these responsibilities might be categorised, building on existing accounts of the various responsibilities of R2P, such as the three-pillar approach and the tripartite distinction in the ICISs report. In particular, it will present six types of international responsibility to protect. In doing so, it will clarify how the responsibilities hang together. It will also highlight underappreciated responsibilities, such as the responsibilities to support other agents and to advance the R2P. Overall, it will argue that the international responsibilities of the R2P are multi-faceted and are borne by a wide variety of actors. In short, there is not simply an international responsibility to protect, but numerous international responsibilities to protect.

The discussion will proceed as follows. I will first outline the centrality of the international responsibility to protect for the R2P. I will then present six forms of international responsibility: (1) the responsibility to undertake direct action; (2) the responsibility to support direct action; (3) the responsibility to authorise; (4) the responsibility not to act; (5) the responsibility to advance R2P; and (6) the responsibility to reform. The final section will specify exactly what it means to say that there is an 'international responsibility to protect'.

\section{The Centrality of the International Responsibility to Protect to R2P}

It is worth first highlighting the centrality of international responsibility to protect to the R2P. Although it was perhaps the chief part of the report by the ICISs, the notion that there is an international responsibility to protect was somewhat (if not fully) downplayed in the 2005 World Summit Outcome Document. ${ }^{9}$ Notwithstanding, the notion of international responsibility is a central part of the approach presented in the UN Secretary General Ban-Ki Moon's 2009 report, Implementing the Responsibility to Protect, which presented the three pillar approach to R2P. ${ }^{10}$ Although pillar one concerns

Welsh, 'Implementing the "Responsibility to Protect"', pp. 129-30. As Alex Bellamy highlights, the Un World Summit Outcome Document still emphasises international responsibilities. These are to assist states to live up to their protection responsibilities and to use appropriate diplomatic, humanitarian and other peaceful means when necessary, "The Responsibility to Protect Turns Ten', p. 169 .

10 Ban Ki-Moon, Implementing the Responsibility to Protect, Report of the Secretary-General, 12 January 2009. Toni Erskine convincingly highlights the stronger sense of responsibility in this report, 'Moral Agents of Protection and Supplementary Responsibilities to Protect', in Alex J. Bellamy and Tim Dunne, Oxford Handbook on the Responsibility to Protect (Oxford: Oxford University Press, forthcoming). 
domestic responsibilities, pillars two and three concern international ones: essentially, the responsibility to assist states (pillar two) and the responsibility to coerce them (pillar three). More recently, the 2014 report on pillar two by the UN Secretary-General, Ban-Ki Moon, makes very clear the import of the international responsibility for $\mathrm{R} 2 \mathrm{P}$ :

The key conceptual move made by the principle of the responsibility to protect was to shift the discussion from the discretion or right of third parties to intervene to the responsibility that a variety of actors have, at different levels, to assist in protecting potential victims of atrocity crimes. ${ }^{11}$

Similarly, the Special Advisor for the UN Secretary-General on R2P, Jennifer Welsh, notes that a core element of R2P is 'the international community's remedial responsibility to act.'.12 Indeed, the notion of international responsibility is widely seen to be what is value-added or novel about R2P. ${ }^{13}$ This is because pillar one responsibilities of $\mathrm{R} 2 \mathrm{P}$ (states' protective responsibilities towards their own populations) were already established in international law and the R2P only really reaffirms these responsibilities (although probably garners more support for them). ${ }^{14}$ The international responsibility to protect is much more novel and is where the R2P can have greatest impact (and arguably has had greatest impact).

Indeed, the central debates surrounding the R2P focus on the international responsibility to protect. Perhaps most notably, the question of whether the R2P is efficacious is seen as depending in large part on the degree of acceptance by states and other actors that there is an international responsibility to protect. Critics in this debate deny that the R2P is efficacious on the basis of the following claims. ${ }^{15}$ (1) R2P's pillar one replicates pre-existing

11 Ban Ki-Moon, Fulfilling our Collective Responsibility: International Assistance and the Responsibility to Protect, Report of the Secretary-General, 11 July 2014, pp. 4-5.

12 Welsh, 'Implementing the "Responsibility to Protect", p. 126.

13 See, for instance, Luke Glanville, 'On the Meaning of "Responsibility" in the "Responsibility to Protect"', Griffith Law Review, 20/2: 482-502 (2014), p. 490.

14 R2P adds impetus to the first pillar by encouraging states to tackle and prevent mass atrocities within their own borders. It has led to some institutional measures, such as the development of R2P focal points.

15 See, for instance, Aidan Hehir, 'The Responsibility to Protect: "Sound and Fury Signifying Nothing"?', International Relations, 24/2: 218-39 (2010); Aidan Hehir, The Responsibility to Protect: Rhetoric, Reality and the Future of Humanitarian Intervention (London: Palgrave Macmillan, 2012); Aidan Hehir, 'The Permanence of Inconsistency: Libya, the Security 
norms and laws. (2) States do not widely endorse the international responsibility to protect (e.g. it is generally absent from UN Security Council resolutions that cite R2P). (3) Even when they openly accept the international responsibility to protect, this does not compel action-words do not turn into deeds. And, (4), even when there is international action, this is not because of R2P.

By contrast, defenders of the efficaciousness of R2P argue that the international responsibility to protect is widely endorsed and does influence states' actions. ${ }^{16}$ They (in my view, plausibly) make the following claims. (1) States have explicitly endorsed the international responsibility to protect. (2) There is criticism of others' inaction in the face of mass atrocities and failures to live up to the international responsibility to protect, showing that conformity to R2P is expected behaviour. (3) There is evidence of influence of R2P in decision-making, such as in the case of Libya. And, (4), there have developed 'habits of protection', whereby the international community now at least does something in response to mass atrocities. For instance, Alex Bellamy argues that the R2P has emerged as an international norm because of 'changes to practice, whereby international responses to genocide and mass atrocities have become more common and more focused on protecting populations' as well as 'critical responses to failures to protect and in the emerging tendency of states... to acknowledge positive duties in this regard'.17

\section{The Duty of Conduct/Responsibility to Try}

Defenders of the efficacy of R2P point, in particular, to the emergence of a 'duty of conduct' or 'responsibility to try', which is an international responsibility to attempt to address or prevent mass atrocities. The international part of R2P, Bellamy argues, comprises a 'responsibility to try' to address mass atrocities. ${ }^{18}$ In similar vein, Welsh argues that it is a 'duty of conduct', by which she

Council, and the Responsibility to Protect', International Security, 38/1: 137-59 (2013); Justin Morris, 'Libya and Syria: R2P and the Spectre of the Swinging Pendulum', International Affairs, 89/5: 1265-83 (2013).

16 For instance, Bellamy, The Responsibility to Protect; Bellamy, 'The Responsibility to Protect Turns Ten'; Welsh, 'Implementing the "Responsibility to Protect".

17 Bellamy, 'The Responsibility to Protect Turns Ten', p. 171.

18 Bellamy, The Responsibility to Protect, p. 72; Bellamy, 'The Responsibility to Protect Turns Ten', p. 171. 
means it 'is primarily a responsibility to consider a real or imminent crisis involving atrocity crimes.' ${ }^{19}$ What exactly does this mean?

First, the duty of conduct/responsibility to try rests on the premise that there is not one blueprint for appropriate action for all cases. What will be an appropriate action depends on its moral justifiability, which will in turn depend on the context, such as the likely effects of the action. To put it briefly, international action under R2P requires horses for courses. ${ }^{20}$

Second, the duty of conduct/responsibility to try is sometimes framed as requiring that 'something be done' and that 'inaction is no longer an option'. However, this is ambiguous. The international R2P does not simply require that something be done. After all, that something might be completely ineffectual. It might be, for instance, simply setting up a peace conference with no hope of this addressing or ameliorating the ongoing mass atrocities. Alternatively, it might be making banal, weak statements in the UN Security Council about the crisis. Rather, the international responsibility to protect requires, as far as possible, effective action to protect populations. Halfhearted attempts are not sufficient to meet the requirements of $\mathrm{R} 2 \mathrm{P}$, that is, the international responsibility to protect threatened populations. Thus, duty of conduct/responsibility to try requires, as far as possible, effective response.

What exactly this response should be will, of course, depend on the context and will be subject to various feasibility constraints. Some crises will require forcible military intervention; others will require far less coercive measures. The importance of context in determining what exactly the responsibility will involve is still consistent with holding that the international community is required to do what it can to address or prevent mass atrocities. As Bellamy notes,

although there is no blueprint for action that works in every case and no requirement that the world must always succeed in its efforts (sometimes even the best of efforts can fail), there is an expectation that governments, acting through their bilateral relationships, regional

19 Ibid., p. 126.

20 Welsh frames the duty of conduct as a requirement to deliberate, that is, a responsibility to consider action. But it is clear from the general thrust of her argument that she means something very similar to the responsibility to try: relevant actors in the international community (e.g. in the UN Security Council) should consider what would be the best course of action in the context and adopt this. 
organizations, ad hoc arrangements, or the various arms of the UN, will try to do what they can to protect populations. ${ }^{21}$

It is worth noting that this potential ambiguity surrounding the duty of conduct/responsibility to try is important for the debate surrounding the efficacy of R2P. To show that the international responsibility to protect is a norm, it needs to be shown that there is a shared expectation that members of the international community must do their best to address mass atrocities, rather than shown that there is an expectation that they merely do something. Those more sceptical might suggest that, although the international community is more engaged, there is evidence to suggest that states accept only a responsibility to try half-heartedly, rather than carrying out fully what is required by the $\mathrm{R} 2 \mathrm{P}$, that is, doing what can be done within the current constraints. In reply, those more optimistic might point to the international condemnation of not simply inaction, but also inadequate action, such as where the international community has been engaged and undertaken some measures, but has not done what it can (such as most notably in response to the mass atrocities in Syria). ${ }^{22}$ This critique of half-hearted measures might suggest acceptance of the responsibility to try to do what one can.

The duty of conduct/responsibility to try is necessarily very general. Thus, I will call it the 'General Requirement' of the international responsibility to protect. Perhaps all actors in the international community possess this General Requirement. That is, all should do their best to tackle mass atrocities. The worry, though, with such generality is that various actors in the international community can shirk their international responsibility because of the vagueness of the General Requirement. They can claim that they have done what they can and other actors cannot easily hold them to account since they cannot point to specific responsibilities that they have failed to act upon. Without specification, then, the General Requirement might not exert sufficient compliance pull on states and other actors. To make the General Requirement of the international responsibility to protect much more determinate and potentially influential, it can — and should be-fleshed out into various specific requirements. ${ }^{23}$

21 Bellamy, The Responsibility to Protect, p. 62; emphasis added.

22 See Glanville, 'Does R2P matter?' for a clear account of the criticism of the inadequate action in Syria.

23 The following section will flesh out these six specific responsibilities. But it should be noted that they may need to be specified even further in order to exert sufficient compliance pull. 


\section{A Typology of the Responsibilities to Protect}

I will now present six specific forms of the international responsibility to protect. ${ }^{24}$ These stem from the General Requirement, that is, they are required by the notion of an international responsibility to protect (that is, to do their best), which, as we have seen, is central to the R2P. It is a further question (which I will not consider) to what extent (1) states accept, either implicitly or explicitly, these particular responsibilities as standards for expected behaviour in the international system-i.e. whether they are norms. States may accept the General Requirement to do their best, which may be a norm, but not have crystallised this into particular responsibilities. It is also a further question to what extent (2) states act upon these responsibilities. Even if they are norms, they may or may not be very influential. I should also add that my aim is not to defend each particular type of responsibility in detail (which space precludes); rather, it is to provide a more broadbrush account of what the specific responsibilities are.

\section{(1) The Responsibility to Undertake Direct Action}

Perhaps most patent is the responsibility to undertake direct action. This includes the duty to intervene militarily (only with the authorisation of the UN Security Council), as well as several different measures of reaction under pillar three, such as to launch international criminal tribunals, as postulated by the 'responsibility to prosecute.'. ${ }^{25}$ There are also responsibilities to launch and maintain economic sanctions, such as the freezing of financial assets, travel bans, and the restriction on the import and/or export of certain goods, such as arms or oil. Perhaps less obvious is that there are responsibilities to name and shame offending states or non-state actors. Such criticism can help to highlight and to address situations, to contribute to raising the reputational costs of future mass atrocities, to help to establish norms such as R2P, and even to punish offenders. ${ }^{26}$ The responsibilities to name and shame are held by states and

24 There may be other forms of the responsibility to protect; I simply focus on those that seem most relevant. Also note that some of these responsibilities may overlap on occasion.

25 To be clear, the examples I present here (and from hereon in) are not meant to exhaust all the possible sorts of measures required by the R2P. They are meant only to be illustrative. The various reports by the UN Secretary-General on the R2P provide a more exhaustive list of potential measures.

26 James Pattison, 'The Ethics of Diplomatic Criticism: The Responsibility to Protect, Just War Theory and Presumptive Last Resort', European Journal of International Relations, forthcoming. 
NGOS, as well as individuals (e.g. academics and journalists). Smaller states are particularly well placed to engage in diplomatic criticism because they, unlike larger, more militarily capable states, tend not to be tarred to such a degree with accusations of hypocrisy, which can weaken the efficacy of such criticism. $^{27}$

The responsibility to undertake direct action also involves responsibilities of reaction under pillar two. This may take the form of a responsibility to help to mediate between parties, which may fall on particular influential individuals. In addition, there may be a responsibility to launch a peacekeeping operation. That is, states have responsibilities to contribute troops to peacekeeping operations. Again, this may be particularly relevant for smaller states who do not already take part in large-scale humanitarian interventions themselves. However, it is also important for states to contribute troops who are well trained and sufficiently equipped to engage in peacekeeping operations. This means that potentially more militarily capable states should carry a significant burden in this regard (and most likely more than they currently have been). ${ }^{28}$

In addition, states and other actors may be required to engage in military action in support of the state against a rebel movement that is committing mass atrocities. Examples include the recent bombing campaigns by France in Mali against Islamist rebels and the US, UK, and other states' action in Iraq against the Islamic State of Iraq and Syria (ISIS) (e.g. in defence of the Yazidis). It is important to highlight here that any such interference would need to meet certain conditions in order to be permissible, which may resemble Just War conditions, such as that found in the ICIss report (the 'Precautionary Principles'). If, for instance, military action in support of the state would worsen the humanitarian situation, it would not be permissible, and so would not be a responsibility. This is despite the fact that the interference has been requested.

Similarly, the responsibility to undertake direct action under pillar two can include a responsibility to provide arms to states when they are facing a rebel movement that is committing mass atrocities. This is only if it would

27 There is also a responsibility to criticise other states for failing to act on their R2P responsibilities. For instance, if the UnSC fails to authorise appropriate action (e.g. in Syria), states may be morally required to denounce the UNSC for their failure. There is, then, not only a duty to criticise the offending states as part of naming and shaming offending states; there is also a duty to name and shame those who could justifiably respond (or support or authorise action) but fail to do so.

28 See Alex J. Bellamy and Paul D. Williams, 'The West and Contemporary Peace Operations', Journal of Peace Research, 46/1: 39-57 (2009). 
avoid long-term problems and make a significant improvement in addressing the mass atrocities. This is generally very unlikely. ${ }^{29}$ Supplying arms will generally be counter-productive since the rebels will engage in an arms race with the state and will steal arms from government stockpiles. It will also often lead to long-term problems since the arms will not be destroyed and will lead to crime or further conflict. And it will generally do little to address mass atrocities because, for instance, the arms will make little difference to the state's capacity to address the mass atrocities. Notwithstanding, if - and it is a very big 'if'-supplying arms would be efficacious (and meet other conditions), the duty to supply arms may be held by a variety of actors, including states that possess these weapons and those that make them.

In addition to the duties of reaction, there are also duties of prevention, for both pillars two and three. For instance, under pillar three, there is a responsibility to prosecute in order to deter future mass atrocities. Under pillar two, preventive measures include encouraging states (such as through the Universal Periodic Review of the Human Rights Council), dialogue and preventative diplomacy, and capacity building to achieve effective and legitimate governance, including developing professional and accountable security services, impartial institutions for political transition, an independent judiciary, and improved early warning of mass atrocities. ${ }^{30}$ Also included under such preventive measures are the responsibilities to rebuild states after conflict. This is to avoid a relapse of the mass atrocities. ${ }^{31}$

\section{(2) The Responsibility to Support}

Thus far, I have focused on agents taking direct action to redress or prevent mass atrocities. This will be well-known territory for those familiar with the R2P. Less appreciated is the fact that there are responsibilities to support. That is, there is a responsibility to support the party that is undertaking direct

\footnotetext{
29 See James Pattison, 'The Ethics of Arming the Rebels', Ethics \& International Affairs, forthcoming.

$3^{0}$ Ban, Fulfilling our Collective Responsibility.

31 I argue elsewhere that the responsibility to rebuild is best seen as an international duty to establish just political institutions, James Pattison, 'Jus Post Bellum and the Responsibility to Rebuild', British Journal of Political Science, 45/3: 635-61 (2015). As such, the responsibility to rebuild is broader than the $\mathrm{R} 2 \mathrm{P}$, since it also concerns more than a responsibility to rebuild in order to avoid mass atrocities. Although just political institutions may be necessary for the prevention of mass atrocities, the prevention of mass atrocities may sometimes require only stable institutions, not just ones.
} 
action. ${ }^{32}$ For instance, if there is a responsibility to launch a peace operation in response to mass atrocities in Burundi (because this would be the most judicious method). It would fall not simply on those whose intervention would be most morally appropriate, such as the African Union (AU), to bear all the burdens of costs of intervening. It would also fall on other members of the international community to help with the burdens of these costs (e.g. the European Union) and to help ensure that the operation is effective and, more precisely, morally justifiable. Supporting responsibilities may involve, for instance, supplying logistical support to the operation, funding it, or providing rhetorical support in order to increase reputational costs on potential opponents.

Supporting responsibilities apply to all the various preventative and reactive measures. They might involve, for instance, helping to establish evidence for an international criminal tribunal, compensating states that impose sanctions and are thus heavily affected by a sanctions regime, or helping a regional organisation to encourage a state to put in place more checks on its security services.

As already alluded to, the importance of such supporting responsibilities is twofold. First, they may be necessary in order to undertake the particular measure in the most efficacious manner, such as by enabling or improving the effectiveness of peace operations. Second, they can help to distribute the burdens of carrying out the measure fairly. Thus, as Kok-Chor Tan's piece in this issue highlights, one of the central issues with the allocation of the international responsibility to undertake humanitarian intervention concerns the fairness of this distribution. ${ }^{33}$ Placing the burdens on those most likely to be justifiable (e.g. because they possess sufficient military capacity to be effective) may appear to be unfair since others should also do their part in tackling mass atrocities.

Notwithstanding, the worries surrounding fairness in the case of humanitarian intervention largely dissipate because the most militarily capable states

$32 \quad$ Duties to support here are more specific than Erskine's interesting notion of 'supporting responsibilities' (in 'Moral Agents of Protection'), which, for her, are duties to put in place the conditions that are necessary for states to live up to their responsibility to protect. Her account of 'supporting responsibilities' is broader, including duties to reform, such as potentially to set up a UN standing army. They are held by third parties to the situation. By contrast, my notion of 'duty to support' here concerns, more specifically, supporting the responses of third parties. (Although I focus on the duty to support direct action, this might be extended to the duty to support others in their authorisation, not acting, and advancing of R2P).

Tan, 'Humanitarian Intervention as a Duty'. 
tend to be rich, Western states that already do very well out of the international system. They also generally fail to fulfil their international responsibilities (e.g. they don't do enough to tackle not only mass atrocities, but also climate change and global poverty). But the worries about fairness have more purchase for peace operations, particularly when they need to be undertaken by African states because, for instance, of their proximity. African states should not have to bear all the costs of such operations; others have a responsibility to support them.

There is a further point worth noting about fairness in the distribution of the international responsibilities to protect. Almost all accounts of fairness in political philosophy require that those most well off, and particularly those that benefit from an unjust global economic system, should carry more of the burdens. Between those who do well out of this system, the costs should be borne more or less equally. The fact that the responsibilities to protect involve far more than simply military intervention, but also a responsibility to engage in a whole host of preventative and reactive measures under pillars two and three, enables the spreading of the more sizable costs of tackling mass atrocities amongst various wealthy agents of the international community. For instance, although France, the Us, and the UK may be morally required to take the lead in instances of mass atrocities, other less militarily capable states, such as Japan and Germany, should carry the costs of fulfilling the responsibilities to protect in other ways, such as by financing and supporting peace operations. Of course, less wealthy states are required to play some role by carrying out and supporting measures that are less costly, such as naming and shaming, especially where they can play a particularly influential role.

\section{(3) The Responsibility to Authorise}

In addition to carrying out and supporting action, there are also responsibilities to authorise the appropriate action. This is held by the institutions that possess the relevant authorisation powers. Most clearly, the UN Security Council has a responsibility to authorise appropriate action, such as by making a referral to the International Criminal Court, authorising a peace operation, and approving economic sanctions. But it is not only the Security Council that possesses this responsibility. Certain regional bodies, such as the AU, may also possess the responsibility to authorise a response, sometimes prior to a Security Council resolution (e.g. in order to pressurise the Council). The domestic institutions of states will also be required to authorise appropriate responses, such as when parliamentary bodies discuss the potential for justifiable military intervention. 


\section{(4) The Responsibility Not to Act}

There is also a responsibility not to act on occasion. This is a responsibility not to undertake, support, or authorise a particular action. To be clear, in virtually all conceivable cases of mass atrocities, there is at least something that can be done. Thus, the 'responsibility not to act' is not a responsibility to do nothing. Rather, it is a responsibility not to undertake, not to support, or not to authorise an inappropriate measure.

What is an inappropriate measure? First, it is a measure that would be likely to do more harm than good, be wrongly motivated, or would cause significant harms to many civilians. For instance, economic sanctions would not be required in a particular case if it would make the situation even worse. Just as humanitarian intervention needs to meet the requisite Just War criteria in order to be a duty, each of the various potential responsibilities need to meet relevant conditions for the measure.

Second, to be appropriate, and therefore a responsibility, a measure needs to be the best option. If there is another measure that would better address or prevent mass atrocities, this measure should be put in place instead. If, for instance, naming and shaming would better address mass atrocities than economic sanctions, even though both measures would do more good than harm, only naming and shaming is permissible. To put this more concretely, to be appropriate, a measure needs not simply to be rightly intended, proportionate, and discriminate; it also needs to be necessary. Necessity here connotes the comparative desirability of the measure, compared to the other potential measures. If it is not necessary, it is inappropriate.

Clearly, a combination of measures will often be the most effective way of addressing or preventing mass atrocities. Indeed, virtually all cases of response to mass atrocities since the 1990s have involved a combination of measures, either concurrently or sequentially. For instance, the most desirable way of addressing an ongoing genocide may be to name and shame the offending state, to launch targeted sanctions on its leaders (e.g. travel bans), and to commence international criminal prosecutions (e.g. by a referral to the International Criminal Court (ICC)), with the conjoined aim of significantly increasing the costs on leaders of maintaining such measures.

The responsibility not to act also requires agents not to exacerbate or increase the likelihood of mass atrocities occurring, in order to realise the prevention of mass atrocities. For instance, states should not supply arms to governments that may be likely to engage in mass atrocities. The responsibility not to act also requires of states and other actors that they not block or hamper potential means of addressing or preventing mass atrocities. Thus, there is a 
'responsibility not to veto'. This applies not simply in cases of potential military intervention, but for any potential measure that will justifiably address or prevent mass atrocities.

\section{(5) The Responsibility to Advance R2P}

Beyond the responsibility to address or prevent a particular crisis, there is also more generally a responsibility to advance $R 2 P$, and related human protection norms, in order to tackle, prevent, and ameliorate future cases of mass atrocities. The goal is to propagate R2P and ultimately to establish it as a norm that achieves full compliance. The affirmation of the R2P (and related human protection norms) can help to improve the compliance pull of the R2P (and related norms) by making it clear what the standards of expected behaviour are in the international system and, in turn, the reputational costs of failing to live up to those standards. These costs are for both those committing the atrocities and those who can potentially act justifiably in response to them. This responsibility might include, for instance, speaking in defence of the R2P in the General Assembly debates. It also applies to individuals, NGOs, and domestic institutions, which should advance the notion that R2P is the appropriate standard of behaviour. The responsibility to advance R2P may also concern concrete measures, such as the institutionalisation of a clear 'R2P focal point' domestically, and signing up to treaties that may enable the R2P (and related human protection norms) to be more easily advanced, such as by ratifying the Rome Statute.

It also involves a responsibility not to weaken the R2P, by misusing it to justify actions outside of the R2P's scope and, in particular, to avoid abusing it. On the one hand, the occasional instance of the mendacious citation of R2P may help to make clear the scope of R2P, as arguably happened in the case of the Russian invocation of R2P when it intervened in Georgia. ${ }^{34}$ On the other, the general abuse of R2P could weaken international support for it if, for instance, it becomes to be seen as largely a tool for rhetorically justifying unilateral interventionism. Similarly, the responsibility to advance R2P also includes a responsibility to advance understanding of R2P, in order to make clear its scope and weaken the traction that mendacious invocations of $\mathrm{R} 2 \mathrm{P}$ receive. This is held by various actors, ranging from individuals, such as academics, journalists, politicians, and those within the un Joint Office of the Special Adviser on the

34 Cristina G. Badescu and Thomas G. Weiss, 'Misrepresenting R2P and Advancing Norms: An Alternative Spiral?', International Studies Perspectives, 11/4: 354-74 (2010). 
Prevention of Genocide and on the Responsibility to Protect, to states, regional organisations, and the UN Security Council.

The responsibility to advance the R2P is premised on the notion that the doctrine of R2P helps in the prevention and tackling of mass atrocities. In reply, it might be thought that it is counter-productive because it blocks the path for other potential means of addressing mass atrocities, such as alternative doctrines of humanitarian intervention or human security, or erodes the political will for more radical institutional change.

Both points are dubious. First, there is not a plausible rival candidate. And even if there were, there would be significant transition costs in abandoning R2P and adopting an alternative. For the last 10 years, and for the foreseeable future, R2P has largely framed the discussion of the tackling of mass atrocities. Adopting an alternative would require significant political will, which would most likely be better spent on promoting the R2P. The amount of effort involved in developing and propagating an alternative, conjoined with the potential risk of undermining the gains that R2P has made, are likely to be too large for too small and uncertain a benefit with another doctrine. ${ }^{35}$ Second, radical institutional change seems unlikely if the international community were to abandon R2P. Rather, what seems far more likely is this: a return to a more sovereigntist international system in which the various members of the international community are not expected to do anything to tackle mass atrocities within the borders of another state. In fact, perhaps the only way that significant institutional reform will be achieved is through the $R 2 P$. That is, reform seems most likely to be achieved by developing sufficient will to reform by reaffirming that there is a responsibility to address mass atrocities beyond the borders of the state and that this responsibility requires reform.

\section{(6) The Responsibility to Reform}

As just indicated, the R2P also necessitates the responsibility to reform. This is in order to be able to better achieve the protection of populations threatened by mass atrocities. As Welsh notes, this might include

the development of stronger capacity for effective mediation among conflicting parties so as to end violence against innocent civilians; the

35 For a more detailed defence of R2P against some of the alternatives (especially radical ones, such as a world government and a new judicial body), see Bellamy, The Responsibility to Protect, pp. 74-92. 
creation of expertise and technology to impose and implement financial sanctions and embargoes against potential perpetrators of crimes; the training and equipping of armed forces for atrocity-prevention missions (including, for example, safe havens and no-fly zones); or the development of technology to block radio transmissions inciting violence or to provide surveillance that deters perpetrators. ${ }^{36}$

The reforms required relate to the particular responsibilities outlined above. First, there are responsibilities to reform so as to better undertake direct action. This might, for instance, require the development of enhanced regional capacity to undertake peace operations and military interventions. Second, there are responsibilities to reform so as to better support others' action. This might include, for instance, a responsibility to improve the funding mechanisms for peace operations. Third, there are responsibilities to reform so as to better authorise the appropriate action. This might require, for instance, reform of the UN Security Council's procedures or membership, such as a code of conduct for the use of the veto in the UN Security Council. Fourth, there are responsibilities to reform so as to better avoid certain actions that may enable or exacerbate mass atrocities. These responsibilities include, for example, increasing the restrictions on the arms trade. Fifth, there are responsibilities to reform so as to better advance R2P. These include, for instance, setting up further civil society organisations in order to improve understanding of R2P. Sixth, the responsibility to reform includes the responsibility to support, to authorise, and not to block the reform efforts of others, such as for a state not to support proposals that are infeasible in order to foreclose change.

Of course, various measures will differ in their degrees of feasibility. Assessments will need to be made of whether it is worth investing political will in measures that are less likely to be feasible but could bring significant benefits in terms of improving the response to mass atrocities. More precisely, there is a responsibility to carry out the reforms that have the largest probability of making the most significant impact on the prevention or tackling of mass atrocities (after taking into account likely transition costs). ${ }^{37}$

36 Welsh, 'Implementing the "Responsibility to Protect", p. 140.

37 For a helpful account of how to conceive of and assess feasibility of reform, see Holly Lawford-Smith, 'Understanding Political Feasibility', Journal of Political Philosophy, 21/3: 243-59 (2013). 


\section{Table of Responsibilities}

The international responsibilities to protect are summarised in the following table.

\section{Responsibilities Examples}

$\begin{array}{ll}\text { Responsibility to } & \text { Pillar two } \\ \text { undertake direct action } & \cdot \text { Helping states to develop early warning capacity } \\ & \cdot \text { Giving advice on good governance } \\ & \cdot \text { Undertaking peacekeeping operations } \\ & \text { Pillar three } \\ & \cdot \text { Undertaking Humanitarian intervention } \\ & \text { Launching economic sanctions } \\ & \cdot \text { Making ICC referral }\end{array}$

Responsibility to support direct action

Responsibility to authorise

Responsibility not to act

Responsibility to advance R2P

Responsibility to reform
Pillar two

- Providing logistical support to peacekeeping operations Pillar three

- Funding of humanitarian intervention

- Helping states to cover costs of a sanctions regime

- Assisting in the finding of information for ICC prosecution

- Authorising humanitarian intervention in UN Security Council

- Authorising international assistance to other states in domestic institutions

- Not launching intervention if will worsen a situation

- Not vetoing coercive action in UN Security Council

- Speaking in defence of R2P

- Advancing understanding of R2P

- Not abusing R2P norm

- Signing up to Rome Statute

- Improving international early warning

- Changing procedures in UN Security Council

- Banning of trade in certain arms

- Improving peacekeeping capacity 


\section{Clarifying International Responsibilities}

Having presented a typology of six forms of the international responsibility to protect, I will now consider further what it means to say that there is an 'international responsibility to protect'. In particular, I will present three clarifications of the meaning of the 'international responsibility to protect' in R2P. In doing so, I hope to clear up some ambiguities and potential (and real) misunderstandings about the nature of this responsibility and the six forms that it can take.

First, the international responsibility in the R2P simply means 'duty'. The responsibility or duty in the $\mathrm{R} 2 \mathrm{P}$ is moral, rather than legal, meaning that there are moral reasons to perform a particular action. Thus, the meaning of duty/ responsibility is simply that there is, all-things-considered, a moral reason to perform an action. As noted above, there cannot be a duty if one cannot permissibly perform the action. For instance, if intervention in Burundi would make the situation even worse, intervention would not be permissible and so there cannot be a duty to intervene in Burundi.

Why is this? According to deontic logic, there cannot be conflicting duties. If one can do only either A or B, one cannot be duty bound to do both A and B. ${ }^{38}$ Thus, a state cannot, for instance, be duty-bound both to advance R2P and not to advance R2P. There may, though, be different conflicting moral reasons to perform actions. For instance, a state may have reasons for and against advancing R2P. Or, a state may have a reason to criticise another state in order to delegitimise a leader, but also possess a reason not to do so because criticising the leader would exacerbate the crisis. But a duty to undertake, support, or authorise, a direct action means that one is morally required to do so; there cannot be a countervailing duty not to undertake, support, or authorise the action. For instance, if there is a responsibility to impose economic sanctions, this means that a state must impose the sanctions. It is duty-bound to do so. Any reasons against imposing sanctions do not outweigh those in favour of it doing so. ${ }^{39}$

38 That said, one might accept the possibility of 'moral dilemmas', which is a technical term in moral philosophy used to denote the possibility of conflicting duties, often in 'dirty hands' cases. But 'moral dilemmas' are at odds with the general thrust of R2P. R2P aims to posit clear action-guiding prescriptions and seems premised on the notion that, even in morally difficult situations, there is a right course of action that can be undertaken without 'regret' (e.g. it accepts that humanitarian intervention is sometimes morally required, despite the various moral problems that it raises).

39 There can, however, be pro tanto duties and responsibilities, which are duties and responsibilities that can be outweighed - they have reasons supporting them but there might be further reasons against. There can also be prima facie duties, which are what appear to be duties at first sight. 
A second clarification concerns the assignment of the R2P. Thus far, the accounts of the assignment of the R2P largely concern the duties of humanitarian intervention. ${ }^{40}$ Yet, for each particular responsibility, agents will need to be assigned the responsibility. For instance, the duties to undertake economic sanctions, to support naming and shaming, to advance the R2P, and so on will need to be assigned.

Whilst the various responsibilities are unassigned, they may, as Tan suggests, be viewed as 'imperfect' duties. ${ }^{41}$ This is in the sense that they are not assigned to any particular agent. Why should we care about assigning imperfect duties - or making them 'perfect'? The clear assignment of which agent bears which responsibility can help to ensure that the responsibility is carried out. It can help to avoid ambiguity and contestation, and ultimately poor performance or non-performance of the duty in question. Thus, the former Special Representative on the R2P, Edward Luck, argues (in the context of the need for institutionalisation of focal points) that ' $[u]$ nless someone is mandated to worry about atrocity crimes, they are not likely to get the urgency or level of attention that effective prevention demands. When everyone is responsible, no one is responsible.42

Such assignment can be (1) institutional, in the sense that the particular roles of each agent are formally set out legally or in an institution, or (2) normative, in the sense that there is a shared expectation that a particular agentor type of agent-will act. In general, institutionalisation, as Tan emphasises, is generally more desirable because it is often more likely to ensure that the assigned agent actually acts. But, pace Tan, we should not put too much stock in institutionalisation. Normative assignment will most likely be required for the foreseeable future: it is simply not feasible to institutionalise all of the various responsibilities surrounding the $\mathrm{R} 2 \mathrm{P}$. All that can be achieved is the development of a shared expectation that a particular agent should act. Nor is institutionalisation always desirable. A normative assignment may sometimes exert sufficient compliance pull on agents and, importantly, be more flexible. That is, it may be more reflective of changes to agent's capabilities. For instance, a

40 See, for instance, Tan, 'Humanitarian Intervention as a Duty'; Kok-Chor Tan, 'The Duty to Protect', in Terry Nardin and Melissa S. Williams (eds.), Nomos XLVII: Humanitarian Intervention (New York: New York University Press, 2006), pp. 84-116. I also consider this issue at length in James Pattison, Humanitarian Intervention and the Responsibility to Protect: Who Should Intervene? (Oxford: Oxford University Press, 2010).

41 Tan, 'The Duty to Protect'; Tan, 'Humanitarian Intervention as a Duty'.

42 Edward Luck, 'The Responsibility to Protect at Ten:The Challenges Ahead', Policy Analysis Brief, The Stanley Foundation, May 2015. 
normative assignment of who should undertake peace operations may be more able to reflect increases and decrease in states' military capability, and therefore ability to undertake the peace operation, than an institutional assignment that formalises exactly which agent should act and soon becomes outdated.

How should the responsibilities be assigned? First and foremost, any agent needs to be able to permissibly undertake, support, or authorise the measure in question. Amongst the pool of those that can permissibly act, we should look primarily to those that will be most effective, measured according to their effect on the enjoyment of basic human rights. This is the core of what I call the 'Moderate Instrumentalist Approach'.43 But effectiveness is not all that matters on this approach: it also matters that the agent undertaking the responsibilities will be likely to do so in a manner that is sufficiently discriminate (i.e. not harm civilians) and, where relevant, sufficiently representative of the opinions of innocent civilians likely to be significantly and negatively affected by the decision to undertake the action. ${ }^{44}$

This leads us to a third important clarification: it is only the assigned agent that possesses the particular responsibility. For instance, it is only the intervener that will be able to intervene most justifiability that has the duty to intervene. ${ }^{45}$ This does not mean that other agents do not bear responsibility for the situation. They possess other responsibilities under the General Requirement to do what they can, which may include financially supporting or authorising the assigned agents' actions, or launching other measures, such as engaging in naming and shaming of the offending state and advancing R2P. And, if the

43 Pattison, Humanitarian Intervention and the Responsibility to Protect.

44 There are also potentially backwards-looking considerations related to whether the agents in question owe duties of reparation because they culpably caused the mass atrocities. Such matters of reparation are relevant for the assignment of burdens in general, but far less so in the context of the R2P. This is because those who are culpable for mass atrocities generally seem very poorly placed to act effectively. Their interference will often be likely to make a situation worse and so they will lack the right to act (and so the duty to do so). Suppose, for instance, that Ethiopia enflames tensions in Eritrea, leading to a severe humanitarian crisis in Eritrea. Subsequently, Ethiopia would, most likely, not be able to permissibly intervene military in Eritrea since it would be subject to much hostility and its intervention may worse the humanitarian crisis.

45 Compare Carla Bagnoli, 'Humanitarian Intervention as a Perfect Duty: A Kantian Argument', in Terry Nardin and Melissa S. Williams (eds), NoMos XLVII: Humanitarian Intervention (New York: New York University Press, 2006), pp. 117-40. 
most justifiable agent fails to act, they may be required to fill the void as the responsibility becomes assigned to them. ${ }^{46}$

\section{Conclusion}

The purpose of this article has been to provide a typology of the international responsibilities to protect. I have presented six forms that these responsibilities can take. There are three points worth reiterating about this account.

First, the international responsibility to protect involves more than simply direct action. It also involves responsibilities to support and to authorise others' actions, as well as to advance the R2P. Second, the responsibility to protect involves not simply the measures that can currently be undertaken, but also the responsibility to reform, so as to be better able to address or prevent mass atrocities. Third, the responsibility to protect is held by many agents. Individuals, firms, NGOs, small states, larger states, regional organisations, and various UN bodies, including — but not limited - to the UN Security Council all have the responsibility to protect. There is, then, not simply one international responsibility to protect, but several. And these international responsibilities require much of the various members of the international community if the promise of realising 'never again' is to be made into reality.

46 Thus, there may need to be what Erskine calls the assignment of 'back-up responsibilities' for when the primary agents fail to act, 'Moral Agents of Protection'. This seems particularly relevant when assigning normatively, rather than institutionally. 